\title{
Endoscopic endonasal transsphenoidal surgery: Analysis of the first 120 cases in the training hospital setting
}

\section{Endoskopik endonasal transsfenoidal cerrahi: Ë̆gitim hastanesinde ilk 120 olgunun analizi}

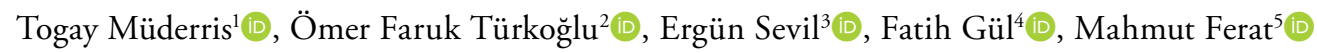 \\ ${ }^{1}$ Department of Otorhinolaryngology, Izmir Bozyaka Training and Research Hospital, Izmir, Turkey \\ ${ }^{2}$ Department of Neurosurgery, Ankara Atatürk Training and Research Hospital, Ankara, Turkey \\ ${ }^{3}$ Department of Otorhinolaryngology, Karaman State Hospital, Ankara, Turkey \\ ${ }^{4}$ Department of Otorhinolaryngology, Yildirım Beyazıt University School of Medicine, Ankara, Turkey \\ ${ }^{5}$ Department of Neurosurgery, 29 Mayıs State Hospital, Ankara, Turkey
}

\begin{abstract}
Objectives: In this study, we report our experience on endoscopic endonasal transsphenoidal surgery among the first 120 consecutive patients and aimed to evaluate the efficacy and safety of the endoscopic two-surgeon, four-hand technique.

Patients and Methods: We retrospectively reviewed the first 120 consecutive patients (67 females, 53 males; mean age 43.14 years; range, 16 to 79 years) who were operated with pure endoscopic endonasal transsphenoidal approach at Ankara Atatürk Training and Research Hospital between January 2011 and January 2015. Tumor removal was performed using the endoscopic binostril bimanual technique. Surgical technique, pathology, intra- and postoperative complications, and surgical outcomes were analyzed.

Results: A total of 91 lesions (76\%) were reported as macroadenoma. Functioning pituitary adenomas were found in 81 patients $(68 \%)$. Of these cases, 28 were prolactinomas (35\%), 35 were growth hormone (GH)secreting tumors $(44 \%)$, and the remainings were adrenocorticotropic hormone $(\mathrm{ACTH})$, follicle-stimulating hormone $(\mathrm{FSH})$, luteinizing hormone (LH), and thyroid-stimulating hormone (TSH)-secreting adenomas. Postoperative complications included transient hyposmia in four patients $(3 \%)$ and diabetes insipidus in eight patients $(6 \%)$, while two of them required permanent vasopressin therapy. Four patients (3\%) anterior pituitary dysfunction and postoperative cerebrospinal fluid (CSF) leak occurred in six patients (5\%). One of them suffered from meningitis. Conclusion: Our study results highlight the value of the collaborative endoscopic endonasal approach as a safe and effective procedure for the management of pituitary tumors. Although an experienced team is required to obtain most favorable results, excellent outcomes can be achieved with two-surgeon, four-hand technique even in new skull base programs.
\end{abstract}

Keywords: Endoscopic, pituitary, transsphenoidal.

\section{$\ddot{O} Z$}

Amaç: Bu çalışmada ilk 120 ardışık hastada endoskopik endonazal transsfenoidal cerrahi deneyimimiz sunuldu ve endoskopik iki cerrah, dört el tekniğinin etkinliği ve güvenliliği değerlendirildi.

Hastalar ve Yöntemler: Ocak 2011 - Ocak 2015 tarihleri arasında Ankara Atatürk Eğitim ve Araştırma Hastanesi'nde tamamen endoskopik endonazal transsfenoidal cerrahi yaklaşımı ile ameliyat edilen ilk 120 ardışık hasta (67 kadın, 53 erkek; ort. yaş 43.14 yıl; dağ 11 m, 16-79 yıl) retrospektif olarak incelendi. Tümör endoskopik binostril bimanuel teknik ile çıkarıldı. Cerrahi teknik, patoloji, ameliyat sırası ve sonrası komplikasyonlar ve cerrahi sonuçlar analiz edildi.

Bulgular: Toplam 91 lezyon (\%76) makroadenom olarak bildirildi. Fonksiyonel hipofiz adenomları 81 hastada (\%68) tespit edildi. Bu olguların 28'i prolaktinom (35\%), 35'i büyüme hormonu (GH) salgılatıcı tümör (\%44) ve geri kalanı adrenokortikotropik hormon (ACTH), folikül stimülan hormon (FSH), luteinizan hormon (LH) ve tiroid stimülan hormon (TSH) salgılatıcı adenomlardı. Ameliyat sonrası komplikasyonlar dört hastada (\%3) geçici hiposmi ve sekiz hastada (\%6) diabetes insipidus olup, bunların ikisinde kalıcı vazopresin tedavisi gerekli oldu. Dört hastada (\%3) ön hipofiz fonksiyon bozukluğu ve altı hastada (\%5) ameliyat sonrası beyin omurilik sıvısı kaçağı görüldü. Bunların birinde menenjit saptandı.

Sonuç: Çalışma sonuçlarımız, hipofiz tümörlerinin tedavisinde iş birliği ile gerçekleştirilen endoskopik endonazal yaklaşımın güvenli ve etkili bir işlem olarak rolünü vurgulamaktadır. En iyi sonuçları yakalayabilmek için deneyimli bir ekip gerekli olmakla birlikte, yeni kafa tabanı programlarında dahi, iki cerrah, dört el tekniği ile mükemmel sonuçlar elde edilebilir.

Anahtar sözcükler: Endoskopik, hipofiz, transsfenoidal.

Received: October 14, 2018 Accepted: January 16, 2019 Published online: March 28, 2019

Correspondence: Fatih Gül, MD. Yıldırım Beyazıt Üniversitesi Tıp Fakültesi Kulak Burun Boğaz Anabilim Dalı, 06800 Bilkent, Ankara, Turkey. e-mail: drfatihgul@gmail.com

\section{Citation:}

Müderris T, Türkoğlu ÖF, Sevil E, Gül F, Ferat M. Endoscopic endonasal transsphenoidal surgery: Analysis of the first 120 cases in the training hospital setting KBB Uygulamaları 2019;7(2):90-96. 
In recent years, endoscopic endonasal transsphenoidal surgery (EETS) has gained great attention and acceptance as the treatment of choice for pituitary region tumors worldwide. During the past two decades, the pure EETS, a minimally invasive approach using the endoscope both for visualization and resection of tumor, has progressively gained popularity among surgeons, who through the pioneering work of Aldo Stamm, Jho, Cappabianca, Carrau and Anand have redefined the limits of transsphenoid approach, using the endoscope to access the whole anterior, middle and posterior skull base..$^{[1,2]}$

The transsphenoidal approach (TSA) for pituitary fossa has been performed microscopically or endoscopically. Although endoscopic transnasal TSA is known a minimally invasive approach, removal of the posterior nasal septum and some trauma to the turbinates is indispensable. The Pittsburgh group claimed that $98 \%$ of patients suffered from nasal crusting for a median of 101.0 days after endoscopic skull base surgery. ${ }^{[3]}$ In contrast, patients who underwent transnasal transseptal microscopic TSA consistently exhibited a relatively clear nasal cavity. ${ }^{[4]}$ As an advantage, EETS provides complete tumor resection, shorter operation time, and minimal perioperative complications. ${ }^{[5]}$ Although use of the endoscope has provided a wider visualization, sometimes this approach offers disastrous complications such as optic nerve injury, hypopituitarism, meningitis and annoying bleeding resulting from carotid artery and cavernous sinus injury. Hence, there is an ongoing debate on the safety and efficacy of this technique in some centers.

Most groups who have promoted a fully endoscopic technique have strongly emphasized the requirement of a two-surgeon, three, or preferably four-hand approach. ${ }^{[6,14,16,17]}$ The most common scenario of this binostril technique consists of an otorhinolaryngologist performing the initial sphenoid exposure, followed by the neurosurgeon removing the bony structures of the skull base and the lesion while the otorhinolaryngologist operates the endoscope.

In this study, we report our experience on EETS among the first 120 consecutive patients and aimed to evaluate the efficacy and safety of the endoscopic two-surgeon, four-hand technique.

\section{PATIENTS AND METHODS}

We retrospectively reviewed the first 120 consecutive patients (67 females, 53 males; mean age 43.14 years; range, 16 to 79 years) who were operated with pure endoscopic endonasal transsphenoidal approach at Ankara Atatürk Training and Research Hospital between January 2011 and January 2015. All operations were performed by two surgeons. A written informed consent was obtained from each patient. The study protocol was approved by the Yildirım Beyazit School of Medicine Ethics Committee. The study was conducted in accordance with the principles of the Declaration of Helsinki.

All patients underwent neurological, ophthalmological and endocrinological evaluations. Evaluations included medical history, physical examination, imaging, blood tests including endocrine screen and visual field testing. All patients also underwent magnetic resonance imaging (MRI) with and without gadolinium preoperatively. In addition, computed tomography (CT) scans of the paranasal sinuses were done in all patients to clarify the anatomy of sphenoid sinus, nasal cavity, and nasal septum.

\section{Surgical technique}

All patients were consulted to the Otolaryngology clinic referred from the Department of Neurosurgery after the decision of surgical intervention was made by the Endocrinology Board which consists of endocrinologists, general surgeons, and neurosurgeons. Preoperative CT and MRI scans were detailly evaluated with nasal cavity using an endoscope. In the operating room, under general anesthesia, the patients were positioned in supine position with head-elevated and the nasal cavities were packed with pledgets soaked in $4 \%$ cocaine which were placed on medial sides of the inferior and middle turbinates through both nostrils for mucosal decongestion and to decrease mucosal bleeding during nasal phase of surgery. The face and the nose were prepped with iodopovidone solution and the patients were aseptically draped. Patients were not catheterized prior to surgery. Any significant septal deviation was corrected via hemitransfixion incision. Correction of septal deviation allowed both nasal cavities to be used for access to the sphenoid sinus during surgery.

A 0 -degree $4 \mathrm{~mm}$ endoscope facilitated with a lens washer was inserted into the nasal cavity from the right nostril, and the middle turbinate was gently pushed laterally to enlarge the corridor between the nasal septum and the middle turbinate. The middle turbinate was not removed since a direct access through paraseptal corridor was obtained with lateralization; however, inferior half of the superior turbinate was excised in most of the cases to expose the natural ostium of the sphenoid sinus. The ostium was widely opened with a microdebrider and/or drill. The same process was also performed through the left nostril. The posterior septal branch of the sphenopalatine artery was consistently found at the inferior aspect of the sphenoethmoidal 
recess. Bleeding from this artery was controlled with the help of cautery, if any. After bilateral large anterior sphenoidotomies were done, posterior nasal septum was removed with a retrograde bone punch and a Kerrison rongeur (Karl Storz, Tuttlingen, Germany). Posterior septectomy creates wide bilateral access to the spheonid sinus and significantly increased instrumental maneuverability and allowed utility of the bimanual technique. Finally, flattening of the sphenovomerine suture and all the sphenoid septa were obtained with the help of a drill to expose the anatomical landmarks inside the sphenoid cavity. The sellar face was exposed revealing optic canals anterolaterally and carotid canals inferolaterally.

Endonasal nasosphenoidal stage was done by otolaryngologist while standing on the right side of the table. Afterwards, the otolaryngologist switched to the left side and the neurosurgeon took place at the right side of the patient. The endoscope was held by the otolaryngologist through the patient's left nostril from now on, also suction, cautery or a dissector could be used by him/her, if needed. The sellar floor was opened by the help of drill or a Kerrison rongeur. Intraoperative micro-Doppler ultrasonography was used before opening of dura to avoid vascular injury in certain cases. The dura was, then, cauterized and incised in the midline, in a cruciate form with a sickle knife (Karl Storz, Tuttlingen, Germany). The tumor bulk often herniates and bulges through the dural opening in cases of macroadenomas. Ring curettes and micro-rongeurs were used to remove tumor. In case of a macroadenoma, the inferior and lateral components of the lesion were removed before the superior aspect to prevent the premature descent of the diaphragm, since it would make more difficult to remove the peripheral parts of the tumor. A lesion involving the medial wall of the cavernous sinus can be removed as well under endoscopic control. As a matter of fact, despite careful manipulation and although use of the endoscope provides a wider visualization, possible venous bleeding from cavernous sinuses can occur, but it can easily be controlled by putting hemostatic agents and cottonoids to compress the medial wall of the cavernous sinus and irrigating with warm saline for a few minutes. Finally, after removal of the tumor, the cavity was assessed with 0 - and 30-degree telescopes for the presence of any residual tumor. The use of the angled endoscopes was the great advantage of the endoscopic approach. It allows a tumor which is traditionally not visible with the standard microscopic approach to be seen and removed under vision. Before closure, hemostasis was ensued with time and/or a hemostatic agent such as Surgicel ${ }^{\circledR}$ or Flosea ${ }^{\circledR}$ noting to remove excess agent.
Repair of skull base defects depended on the nature of the defect. If no cerebrospinal fluid (CSF) leak was observed, only Gelfoam was placed within the pituitary fossa and sphenoid sinus, the middle turbinates were repositioned in their correct orientation and the operation was complete. No packing was placed in the nasal cavity. If the patient had a small CSF leak from the diaphragm, a small piece of fat or collagen matrix was used to plug the defect, while a multilayered reconstruction with two layers of fascia lata, abdominal fascia or artificial dura (Durepair ${ }^{\circledR}$ dura regeneration matrix, Medtronic, MN, USA) placed intra/extradurally beyond the dural margins, and a vascularized mucosal flap originated from middle turbinate covered with fibrin glue (TISSEEL ${ }^{\circledR}$, Baxter Medical, Deerfield, IL, USA). Packing of the sella with fat was only employed for very large CSF leaks. Postoperative nasal packing with paraffin-soaked ribbon gauze was used routinely in all cases with CSF leak.

Patients were discharged from the neurosurgery department after removal of the nasal packing at postoperative third day, if no complication was observed, and the patients were instructed to wash the nasal cavities with a hypertonic saline solution for a couple of weeks, to prevent endonasal synechiae and to clear nasal passage from blood clots.

\section{RESULTS}

The mean follow-up was 12 (range, 4 to 32 ) months. The mean hospital stay was 4.6 (range, 3 to 12) days. Common initial clinical presentations were headache and visual field defect. A total of 91 patients $(76 \%)$ had macroadenoma. Functioning pituitary adenomas were found in 81 patients (68\%). Of them, 28 (35\%) had prolactinoma, 35 (44\%) had growth hormone $(\mathrm{GH})$-secreting tumors, and the remainings were adrenocorticotropic hormone $(\mathrm{ACTH})$, folliclestimulating hormone (FSH), luteinizing hormone $(\mathrm{LH})$, and thyroid-stimulating hormone (TSH)-secreting adenomas. Complete tumor resection was achieved in 104 patients. Our technique allowed preserving more septal mucosa. As a result, sinonasal functions such as nasal breathing and olfaction could be preserved maximally.

No patients had postoperative epistaxis and there were six patients (5\%) with transient hyposmia which were all nonfunctioning macroadenoma cases (Table 1). All patients had recovered from hyposmia 


\begin{tabular}{|c|c|c|c|c|}
\hline \multicolumn{5}{|c|}{$\begin{array}{c}\text { Table } 1 \\
\text { Procedure-related complications }\end{array}$} \\
\hline Type of complication & Age/Gender & Lesion type & Onset of complication & Treatment \\
\hline \multirow[t]{7}{*}{ Hyposmia } & $55 / \mathrm{M}$ & Macroadenoma, NF & $3^{\text {th }}$ week & Medical \\
\hline & $38 / \mathrm{M}$ & Macroadenoma, NF & $3^{\text {th }}$ week & Medical \\
\hline & $58 / \mathrm{M}$ & Macroadenoma, NF & $3^{\text {th }}$ week & Medical \\
\hline & $47 / \mathrm{F}$ & Macroadenoma, NF & $3^{\text {th }}$ week & Medical \\
\hline & $44 / \mathrm{M}$ & Macroadenoma, prolactin & $3^{\text {th }}$ day & ELD \\
\hline & $58 / \mathrm{M}$ & Macroadenoma, NF & $2^{\text {nd }}$ day & Surgery \\
\hline & $54 / \mathrm{F}$ & Macroadenoma, NF & $2^{\text {nd }}$ day & Surgery \\
\hline \multirow[t]{3}{*}{ Postoperative CSF leak } & $32 / \mathrm{F}$ & Macroadenoma, prolactin & $4^{\text {th }}$ day & Surgery \\
\hline & $36 / \mathrm{F}$ & Macroadenoma, prolactin & $4^{\text {th }}$ day & Surgery \\
\hline & $49 / \mathrm{F}$ & Macroadenoma, NF & $4^{\text {th }}$ day & Surgery \\
\hline \multirow[t]{2}{*}{ Meningitis } & $54 / \mathrm{F}$ & Macroadenoma, NF & $7^{\text {th }}$ day & Medical \\
\hline & $34 / F$ & Macroadenoma, prolactin & $\begin{array}{l}7^{\text {th }} \text { day, cortisol and } \\
\text { thyroid deficiency }\end{array}$ & $\begin{array}{l}\text { Still thyroid } \\
\text { replacement therapy }\end{array}$ \\
\hline \multirow[t]{3}{*}{$\begin{array}{l}\text { Anterior pituitary } \\
\text { dysfunction }\end{array}$} & $41 / \mathrm{F}$ & Macroadenoma, NF & $\begin{array}{l}5^{\text {th }} \text { day, ACTH } \\
\text { deficiency }\end{array}$ & \\
\hline & $64 / \mathrm{M}$ & Macroadenoma, NF & $\begin{array}{l}7^{\text {th }} \text { day ACTH } \\
\text { deficiency }\end{array}$ & \\
\hline & $59 / \mathrm{M}$ & Macroadenoma, NF & $\begin{array}{l}8^{\text {th }} \text { day ACTH } \\
\text { deficiency }\end{array}$ & \\
\hline Diabetes insipidus $(\mathrm{n}=8)$ & & All macroadenoma & $1^{\text {st }}$ week & $\begin{array}{l}\text { Two of them } \\
\text { required permanent } \\
\text { vasopressin nasal } \\
\text { spray treatment }\end{array}$ \\
\hline
\end{tabular}

after three months. None of the patients developed anosmia.

Six patients (5\%) who had postoperative CSF leak and also had macroadenomas. Three of them had prolactin (PRL)-secreting macroadenoma, while the other three had non-secreting tumors. The leakage was observed on postoperative Days 3, $4(\mathrm{n}=3)$, and $5(\mathrm{n}=2)$, and an endoscopic revision was required in five patients, while a patient was successfully treated with lumbar drain. All CSF leaks were repaired with multilayer technique. A double layer of artificial dura graft or autologous fascial graft was placed both underlay and overlay, and they were supported with middle turbinate flap. Four postoperative CSF leaks were occurred in the first 15 cases, and only two CSF leak was observed in the last 105 cases. Of these six patients with CSF leak, one also suffered from meningitis. A 54-year-old female patient with PRLsecreting macroadenoma had postoperative headache, fever, and loss of consciousness seven days after the first two days following the second operation. She was reoperated for postoperative CSF leak on the fifth day of surgery and was given appropriate parenteral antibiotics according to the microbiological results. She eventually recovered without any complication or sequelae.

There were four patients (3\%) of new hormonal deficit of anterior pituitary hormones. None of the patients lost hypothalamic-pituitary-adrenal axis function. A 34-year-old female patient with PRL-secreting macroadenoma sized $>4 \mathrm{~cm}$ suffered from hypothyroidism and cortisol deficiency seven days after surgery. The other three patients experienced ACTH deficiency on postoperative Days 5 and 8. At three months of follow-up, serum cortisol levels were normalized in all of these patients, while one of them who had thyroid deficiency required permanent thyroid replacement therapy. In addition, eight patients (6\%) experienced diabetes insipidus after surgery and six of them recovered spontaneously, while the 
remaining two required permanent vasopressin nasal spray treatment.

There was no serious vascular complication. Only one patient had intensive bleeding from intercavernous sinuses which was controlled successfully during operation. None of the patients had postoperative severe epistaxis. No cases of major morbidity, except for a patient suffering from meningitis, or mortality were seen.

\section{DISCUSSION}

The endoscopic technique in skull base surgery offers certain advantages arising from the use of the endoscope itself; a superior close-up view of the relevant anatomy and an enlarged working angle are provided with an increased panoramic vision inside the surgical area. ${ }^{[7,8]}$ One of the most important advantages of this technique is the ability of removal of the tumor which embraces vascular and neural structures by means of angled endoscopes. Although resection of a gross tumor completely by using the endoscopic way seems to preferable method, it can be associated with higher rates of complications such as CSF leaks, vascular injury and hormonal deficiency which can be explained by the demand of removing the tumor completely. Our experience demonstrates that EETS is minimally invasive, effective surgical way with low morbidity which can be successfully utilized with collaborative work of neurosurgeons and otolaryngologists. However, this procedure is technically exhausting and needs some additional specific endoscopic skills.

Surgeons should be careful, while removing posterior part of the septum and opening the sphenoid sinus to avoid complications regarding to injury of the sphenopalatine artery and olfactory fibers. Nasal vascular complications due to bleeding from posterior septal branch of sphenopalatine artery are described in 0.7 to $7 \%$ of cases treated endoscopically. ${ }^{[9-13]} \mathrm{We}$ observed only one case of nasal bleeding (0.01\%) from posterior septal branch during surgery, and bleeding was controlled with the help of cautery and the operation continued as usual. In addition, while removing the tumor in the sellar area, caroticooptic recesses should be recognized clearly and care should be taken for unintentional injury of cavernous sinus and carotid artery.

Comparison with previous microsurgical series highlights the lower overall complication rate, shorter hospitalization and operation time achieved by the endoscopic approach, with low morbidity. Some surgeons advocate two-surgeon technique as the only realistic method for performing these procedures, particularly while performing expanded endonasal operations requiring wider exposures and intracranial dissection. ${ }^{[14-18]}$ We believe this is true for most of the skull base cases, as the binostril bimanual technique with two surgeons provides better visualization, lower complication rate with improved surgical resection and outcomes. The main advantages of the endoscopic transseptal approach for resecting pituitary tumors are the possibility of a binostril approach that allows for a twosurgeon, four-hand surgery and maximal preservation of sinonasal function. Furthermore, if surgeon encounters a vascular complication, the second surgeon who is also experienced in endoscopic surgery can assist rapidly to control bleeding. Nevertheless, surgical experience in endoscopic methods and familiarity of parasellar and pituitary region anatomy results in better outcomes, as well. Our experience on intra- and postoperative CSF leaks supports these concepts. In our series, four postoperative CSF leaks were observed in the first 15 cases, and only two CSF leak was occurred in the last 105 cases. Previously reported rates of postoperative CSF leaks after endoscopic approaches range between 0.5 and 18\%. ${ }^{[19-21]}$ Postoperative CSF leaks occurred in six patients (5\%) in our series. Our complication rate is similar to other pure endoscopy series with a prominent decrease with our increased experience on dural repair techniques with layered and vascularized grafts. Of note, CSF leak risk is reported to be higher in macroadenomas than microadenomas. ${ }^{[9,20]}$ In our cases, all patients with postoperative CSF leaks were operated for macroadenomas, which is also consistent with the literature.

Mucoceles, fracture of the sphenoidal bone, injury of the optic nerves and postoperative infection of the sinus are reported complications related to the sphenoid sinus surgeries. ${ }^{[10,19-23]}$ One of our patients suffered from postoperative sinusitis which was treated with antibiotics. Meningitis is the most important complication which may result in death or sequelae and prolongs the hospitalization. Of these six patients with CSF leak, one suffered from meningitis. In the previous reports, the rate of meningitis has been presented as 0.4 to $2 \%{ }^{[19-21]}$

One of the catastrophic complications of pituitary surgery is vascular injury. In our series, there was only one patient with cavernous sinus injury. Our vascular complication rate is less than $0.5 \%$ which is lower than the previous reports. The rate of vascular injury has been reported as 0.8 to $1.85 \%$ in the literature, ${ }^{[23-26]}$ although we consider that this is due to our small sample size. In previous reports, a maneuver for controlling serious bleedings is described; moving the endoscope back to the level of middle turbinate, packing the sella or sphenoid 
sinus with cottonoids or homeostatic agents. ${ }^{[27]}$ In our case, bleeding was controlled by placing hemostatic agents and cottonoids to compress the medial wall of the cavernous sinus. After the bleeding was controlled, the operation continued as usual.

The temporary form of anterior pituitary dysfunction may be secondary even to simple manipulation of the pituitary gland and/or skull base structures. ${ }^{[28]}$ In our experience, if the surgeon did more inappropriate manipulation and over resection of normal pituitary gland while removing the adenoma tissue, the risk of anterior pituitary deficiency would be higher. In addition, another reason is using excessive bipolar coagulation in sellar cavity. Therefore, higher coagulation increases bleeding. Instead of this, putting a nasal packing hold on a moment or surgical is quite enough.

In conclusion, our study results show that EETS is a safe, minimally invasive, and effective surgical way that can be successfully used in pituitary region tumors. Although an experienced team is required to obtain most favorable results, excellent outcomes can be achieved with two-surgeon, four-hand technique even in new skull base programs.

\section{Declaration of conflicting interests}

The authors declared no conflicts of interest with respect to the authorship and/or publication of this article.

\section{Funding}

The authors received no financial support for the research and/or authorship of this article.

\section{REFERENCES}

1. Stamm AC, Pignatari SS, Vellutini E. Transnasal endoscopic surgical approaches to the clivus. Otolaryngol Clin North Am 2006;39:639-56.

2. Anand VK, Schwartz TH, Hiltzik DH, Kacker A. Endoscopic transphenoidal pituitary surgery with real-time intraoperative magnetic resonance imaging. Am J Rhinol 2006;20:401-5.

3. de Almeida JR, Snyderman CH, Gardner PA, Carrau RL, Vescan AD. Nasal morbidity following endoscopic skull base surgery: a prospective cohort study. Head Neck 2011;33:547-51.

4. Hong SD, Nam DH, Seol HJ, Choi NY, Kim HY, Chung $\mathrm{SK}$, et al. Endoscopic binostril versus transnasal transseptal microscopic pituitary surgery: Sinonasal quality of life and olfactory function. Am J Rhinol Allergy 2015;29:221-5.

5. Zhang X, Fei Z, Zhang W, Zhang JN, Liu WP, Fu LA, et al. Endoscopic endonasal transsphenoidal surgery for invasive pituitary adenoma. J Clin Neurosci 2008;15:241-5.

6. Erkul E, Güngör A, Çolak A, Cincık H, Yıldız K. Endoskopik transsfenoidal yaklaşımla hipofiz adenomu cerrahisi. KBB-Forum 2012;11:93-100.

7. Cappabianca P, Alfieri A, de Divitiis E. Endoscopic endonasal transsphenoidal approach to the sella: towards functional endoscopic pituitary surgery (FEPS). Minim Invasive Neurosurg 1998;41:66-73.

8. Carrau RL, Jho HD, Ko Y. Transnasal-transsphenoidal endoscopic surgery of the pituitary gland. Laryngoscope 1996;106:914-8.

9. Frank G, Pasquini E, Farneti G, Mazzatenta D, Sciarretta $\mathrm{V}$, Grasso V, et al. The endoscopic versus the traditional approach in pituitary surgery. Neuroendocrinology 2006;83:240-8.

10. Rudnik A, Kos-Kudła B, Larysz D, Zawadzki T, Bazowski P. Endoscopic transsphenoidal treatment of hormonally active pituitary adenomas. Neuro Endocrinol Lett 2007;28:438-44.

11. Kabil MS, Eby JB, Shahinian HK. Fully endoscopic endonasal vs. transseptal transsphenoidal pituitary surgery. Minim Invasive Neurosurg 2005;48:348-54.

12. Pádua FG, Voegels RL. Severe posterior epistaxis-endoscopic surgical anatomy. Laryngoscope 2008;118:156-61.

13. Ciric I, Ragin A, Baumgartner C, Pierce D. Complications of transsphenoidal surgery: results of a national survey, review of the literature, and personal experience. Neurosurgery 1997;40:225-36.

14. Özalp H, Kahiloğulları G, Seçinti KD, Tetik B, Bozkurt M, Meço C ve ark. Hipofiz cerrahisi'nde endoskopik ve mikroskopik transsfenoidal yaklaşımların karşılaştırılması. Türk Nöroşir Derg 2015;25:27-37

15. Yano S, Kawano T, Kudo M, Makino K, Nakamura H, Kai $\mathrm{Y}$, et al. Endoscopic endonasal transsphenoidal approach through the bilateral nostrils for pituitary adenomas. Neurol Med Chir (Tokyo) 2009;49:1-7.

16. de Divitiis E, Cavallo LM, Esposito F, Stella L, Messina A. Extended endoscopic transsphenoidal approach for tuberculum sellae meningiomas. Neurosurgery 2007;61:229-37.

17. de Divitiis E, Cappabianca P, Cavallo LM, Esposito F, de Divitiis O, Messina A. Extended endoscopic transsphenoidal approach for extrasellar craniopharyngiomas. Neurosurgery 2007;61:219-27.

18. Laufer I, Anand VK, Schwartz TH. Endoscopic, endonasal extended transsphenoidal, transplanum transtuberculum approach for resection of suprasellar lesions. J Neurosurg 2007;106:400-6.

19. Cappabianca P, Cavallo LM, Colao A, de Divitiis E. Surgical complications associated with the endoscopic endonasal transsphenoidal approach for pituitary adenomas. J Neurosurg 2002;97:293-8.

20. Zhou T, Wei SB, Meng XH, Xu BN. Pure endoscopic endonasal transsphenoidal approach for 375 pituitary adenomas. Zhonghua Wai Ke Za Zhi 2010;48:1443-6.

21. Zhang Y, Wang Z, Liu Y, Zong X, Song M, Pei A, et al. Endoscopic transsphenoidal treatment of pituitary adenomas. Neurol Res 2008;30:581-6.

22. Rotenberg B, Tam S, Ryu WH, Duggal N. Microscopic versus endoscopic pituitary surgery: a systematic review. Laryngoscope 2010;120:1292-7. 
23. Laws ER Jr. Vascular complications of transsphenoidal surgery. Pituitary 1999;2:163-70.

24. Rudnik A, Zawadzki T, Wojtacha M, Bazowski P, Gamrot J, Galuszka-Ignasiak B, et al. Endoscopic transnasal transsphenoidal treatment of pathology of the sellar region. Minim Invasive Neurosurg 2005;48:101-7.

25. Santos Rde P, Zymberg ST, Abucham Filho JZ, Gregório LC, Weckx LL. Endoscopic transnasal approach to sellar tumors. Braz J Otorhinolaryngol 2007;73:463-75.

26. Minet WW, Sommer DD, Yousuf K, Midia M, Farrokhyar F, Reddy K. Retrospective comparison of an endoscopic assisted versus a purely endoscopic approach to sellar tumour resection. J Otolaryngol Head Neck Surg 2008;37:759-67.

27. O’Malley BW Jr, Grady MS, Gabel BC, Cohen MA, Heuer GG, Pisapia J, et al. Comparison of endoscopic and microscopic removal of pituitary adenomas: singlesurgeon experience and the learning curve. Neurosurg Focus 2008;25:10.

28. Berker M, Hazer DB, Çehreli M, Akça K, Salmon P, Tekdemir I. Micro CT analysis of pituitary adenomas. Acta Endocrinol (Buc) 2010;6:481-92. 